\title{
ASAS - ASAS UMUM PERADILAN YANG BAIK MENURUT KONSEPSI MAHKAMAH AGUNG REPUBLIK INDONESIA
}

\author{
GANA ARIA TAMA \\ ghanaaryatama@gmail.com \\ 1910003600014 \\ UNIVERSITAS EKA SAKTI PADANG
}

\section{A.PENDAHULUAN}

Negara Indonesia adalah negara hukum. Sebagai negara hukum, penyelenggaraan negara dengan perantaraan pemerintah harus berdasarkan hukum. Penyelenggaraan pemerintahan dilaksanakan oleh aparat pemerintahan sesuai dengan kewenangan yang dimiliki berdasarkan pengaturan yang telah dibentuk dalam perundang-undangan. Segala hal yang berkaitan dengan penatalaksanaan pemerintahan termasuk tindakan hukum penyelenggaraan pemerintahan juga memerlukan pengaturan yang jelas baik jenis tindakan hukum maupun asas yang menjadi dasar penyelenggaraan pemerintahan yaitu asas-asas umum peradilan yang baik. Penyelenggaraan peradilan berdasar hukum dan asas-asas peradilan yang baik, dengan menjunjung prinsip persamaan di depan hukum. Penyelenggaraan peradilan meliputi semua aktivitas yang dilakukan oleh badan dan / atau pejabat Pemerintahan yang menyelenggarakan fungsi peradilan dalam lingkup lembaga eksekutif, lingkup lembaga legislatif, lingkup lembaga yudikatif serta yang menyelenggarakan fungsi pemerintahan yang disebut dalam UUD 1945 dan/ atau undangundang.

Beberapa asas dalam AUPB juga sering kali diberikan makna yang rancu oleh Hakim dalam pertimbangan hukumnya, misalnya kerancuan antara penggunaan asas proporsionalitas dan asas perlakuan yang sama, atau kerancuan antara penggunaan asas kepastian hukum dan asas profesionalitas. Belum adanya satu pedoman atau panduan yang 
mengatur mengenai indikator masing-masing asas dalam AUPB, menyebabkan masih adanya perbedaan penafsiran dalam membuktikan pelanggaran AUPB oleh Hakim PTUN di dalam praktiknya.Oleh karena itu, perlu kiranya Mahkamah Agung untuk merumuskan indikator masing-masing asas AUPB, sehingga dapat dijadikan rujukan bagi Hakim TUN di semua tingkatan peradilan dalam memutus perkara. Penelitian ini berhasil menyusun beberapa indikator dari 23 asas dalam AUPB yang dirumuskan dari definisi masing-masing asas yang tertera pada bagian Penjelasan 7 UU terkait, dari pendapat berbagai pakar, serta dari indikator yang disarikan dari pertimbangan hukum Hakim dalam berbagai yurisprudensi Mahkamah Agung atau putusan Hakim TUN di tingkat pertama atau banding yang dapat memberikan arahan bagi penerapan AUPB. Temuan indikator-indikator yang telah berhasil dirumuskan dalam penelitian ini, kiranya dapat dijadikan alternatif rujukan (sementara) bagi Hakim dalam memutus perkara, sampai dengan disusunnya indikator AUPB oleh Mahkamah Agung.

Ketentuan isi Pasal 4 ayat (1) UU No. 30 Tahun 2014 itu menunjukkan bahwa pengertian pemerintahan yang digunakan adalah pemerintahan dalam arti luas Sesuai dengan pasal 24 Undang-Undang Dasar Negara Republik Indonesia Ayat (2) Kekuasaan Kehakiman dilakukan oleh sebuah Mahkamah Agung Republik Indonesia dan Badan Peradilan yang berada di bawahnya dalam lingkungan Peradilan Umum, lingkungan Peradilan Agama, lingkungan Peradilan Militer, lingkungan Peradilan Tata Usaha Negara dan oleh sebuah Mahkamah Konstitusi.Sesuai dengan Undang Undang Republik Indonesia Nomor 48 Tahun 2009 tentang Kekuasaan Kehakiman, pada pasal 1 angka 1 dijelaskan bahwa Kekuasaan Kehakiman adalah kekuasaan negara yang merdeka untuk menyelenggarakan peradilan guna menegakkan hukum dan keasilan berdasarkan Pancasila dan Undang-Undang Dasar Negara Republik Indonesia Tahun 1945, demi terselenggaranya Negara Hukum Republik Indonesia. Dengan demikian kedudukan Mahkamah Agung menjadi salah satu pilar utama dalam menjamin terlaksananya kepastian hukum negara ini. 


\section{B.PEMBAHASAN}

Mahkamah agung adalah lembaga tertinggi dalam system ketatanegaraan Indonesia yang merupakan pemegang kekuasaan kehakiman bersama-sama dengan Mahkamah Konstitusi. Mahkamah agung membawahi badan peradilan dalam lingkungan peradilan umum, lingkungan peradilan agama, lingkungan peradilan militer, lingkungan peradilan tata usaha Negara. Saat ini lembaga Mahkamah Agung berdasarkan pada UU. No. 48 Tahun 2009 tentang kekuasaan kehakiman UU ini juga telah mencabut dan membatalkan berlakunya UU No. 4 tahun 2004. Undang-undang ini di susun karena UU No.4 Tahun 2004 secara substansi dinilai kurang mengakomodir masalah kekuasaan kehakiman yang cakupannya cukup luas, selain itu juga karena adanya judicial review ke Mahkamah Konstitusi atas pasal 34 UU No.4 Tahun 2004, karena setelah pasal dalam undang-undang yang di-review tersebut diputus bertentangan dengan UUD, maka saat itu juga pasal dalam undang-undang tersebut tidak berlaku, sehingga untuk mengisi kekosongan aturan/hukum, maka perlu segera melakukan perubahan pada undang-undang dimaksud.

Badan peradilan dalam melaksanakan tugasnya menyelesaikan perkara harus memutus dengan tidak memihak, berdasarkan fakta-fakta dan sesuai dengan hukum, tanpapembatasan; pengaruh yang tidak tepat; bujukan; tekanan; ancaman atau intervensi baik langsung maupun tidak langsung dari pihak mana pun atau untuk alasan apapun. Peradilan memiliki yurisdiksi terhadap isu hukum apapun dan harus memiliki kewenangan eksklusif untuk memutuskan apakah isu yang diajukan kepadanya sesuai dengan kompetensinya sebagaimana didefinisikan oleh hukum. Tidak boleh ada campur tangan yang tidak pantas atau tidak beralasan dalam proses peradilan.Hakim dalam melaksanakan tugasnya harus memastikan hak setiap orang untuk mendapat proses peradilan yang adil,dalam waktu yang dapat dipertanggungjawabkan oleh pengadilan yang independen dalam menentukan hak-hak 
sipil atau tindak pidana yang akan dijatuhkan.Independensi Hakim sangat dibutuhkan untuk keadilan yang tidak memihak berdasarkan hukum.Independensi peradilan merupakan prasyarat untuk terwujudkan negara hukum dan jaminan fundamental terhadap peradilan yang adil. Seorang hakim harus menjunjung tinggi independesi peradilan baik dari aspek individu maupun institusi. Sebagai salah satu Lembaga kekuasaan kehakiman, Mahkamah Agung mempunyai Tugas sebagaimana tercantum dalam Undang-Undang Nomor 14 Tahun1985 pasal 28 : (1) Mahkamah Agung bertugas dan berwenang memeriksa dan memutus :a. Permohonan kasasi; b.Sengketa tentang kewenangan mengadili; c.Permohonan Peninjauan Kembali putusan Pengadilan yang telah memperoleh kekuatan hukum tetap.

Istilah 'asas' dalam Asas Umum Peradilan yang Baik, atau sebagai 'asas hukum', yaitu suatu asas yang menjadi dasar suatu kaidah hukum. Asas hukum adalah asas yang menjadi dasar pembentukan kaidah-kaidah hukum, termasuk juga kaidah hukum tata pemerintahan. Kaidah atau norma adalah ketentuan-ketentuan tentang bagaimana seharusnya manusia bertingkah laku dalam pergaulan hidupnya dengan manusia lainnya. Ketentuan tentang tingkah laku dalam hubungan hukum dalam pembentukannya, sekaligus penerapannya, didasarkan pada asas-asas hukum yang diberlakukan. Perlakuan asas hukum dalam lapangan hukum tata pemerintahan sangat diperlukan, mengingat kekuasaan aparatur pemerintah memiliki wewenang yang istimewa, lebih-lebih di dalam rangka penyelenggaraan kesejahteraan dan kepentingan umum. Kata 'umum' berarti sesuatu yang bersifat menyeluruh dan mencakup hal-hal yang bersifat mendasar dan diterima sebagai prinsip oleh masyarakat secara umum. Kata 'pemerintahan' disebut juga sebagai Badan atau Pejabat Tata Usaha Negara yang dirumuskan dalam Pasal 1 angka 2 Undang-undang Nomor 5 Tahun 1986, menyatakan Badan atau Pejabat Tata Usaha Negara adalah Badan atau Pejabat yang melaksanakan urusan pemerintahan, berdasarkan peraturan perundang-undangan yang 
berlaku. Penjelasan atas Pasal 1 angka 1 menyatakan bahwa yang dimaksud dengan urusan pemerintahan adalah kegiatan yang bersifat eksekutif.

Peradilan adalah pelaksanaan hukum dalam hal ada tuntutan hak yang konkret, fungsi mana dijalankan oleh suatu badan yang berdiri sendiri dan diadakan oleh negara serta bebas dari pengaruh apa atau siapapun dengan cara memberikan putusan yang bersifat mengikat dan bertujuan mencegah eigenrichting. "Pelaksanaan hukum dalam hal ada tuntutan hak yang konkret" berarti bahwa tuntutan hak ini nyata-nyata ada dan diajukan ke pengadilan, suatu badan yang diadakan oleh negara, yang bebas dari pengaruh yudisiil maupun extra-yudisiil. pelaksanaan hukum itu terjadi dengan suatu putusan, yang bersifat mengikat para pihak, definif dan tuntas. Tuntutan hak yang dimaksudkan adalah tindakan untuk memperoleh perlindungan hukum tanpa bertindak menghakimi sendiri (eigenrichting).

Ada Beberapa Asas-asas peradilan yang baik adalah,sbb :

1. Penerapan Asas retroaktif, Dari sisi pengetahuan hukum, asas retroaktif dapat diberlakukan secara rigid dan darurat limitatif, artinya apabila negara dalam keadaan darurat (abnormal) maka pemerintah harus menerapkan prinsip-prinsip hukum darurat (abnormaal recht), karena itu penempatan asas ini hanya bersifat temporer, jika jika kondisi negara sudah normal maka asas retroaktif tidak diberlakukan lagi. Dalam penerapan asas retroaktif harus memerhatikan prinsip-prinsip hukum universal sehingga tidak terkontaminasi dengan unsur-unsur yang dapat dikategorikan sebagai abuse of power.

2. Asas Persamaan di Mata Hukum, Setiap orang mempunyai kedudukan yang sama di depan hukum. Ini adalah salah satu asas peradilan yang merdeka dan fair yang berlaku secara universal. Asas ini merupakan larangan terhadap perlakuan diskriminatif baik berdasarkan suku, agama, kebangsaan, mapun berdasarkan kedudukan atau jabatan. 
Aparat peradilan tidak diperbolehkan berlaku diskriminatif terhadap siapa pun yang mencari kedilan.

3. Asas Persidangan yang terbuka untuk umum, Asas persidangan yang terbuka untuk umum sangat menunjang kemandirian kekuasaan kehakiman. Asas persidangan yang terbuka untuk umum bertujuan untuk menjamin para pencari keadilan untuk mendapatkan akses informasi terhadap jalannya persidangan. Untuk itu bukan berarti setiap orang harus datang ke persidangan untuk mengetahui jalannya persidangan, tetapi masyarakat dapat memperolehnya dari media massa dan sebagainya. Karena itu pengadilan harusmenjamin akses media massa meliput persidangan. Asas ini memberikan kontrol publik terhadap putusan-putusan pengadilan

4. Asas Perlindungan korban dan saksi, Asas ini terkadang terabaikan. Perlindungan saksi dan korban adalah merupakan persoalan penting dalam setiap kasus kejahatan. Urgensi atas perlindungan saksi dan korban ini adalah karena jenis kejahatan yang terjadi dan pelaku yang selalu mempunyai kekuatan dan sumber daya yang luar biasa untuk melakukan upaya-upaya intimidasi dan tekanan kepada korban maupun saksi.

Penjelasan mengenai asas keadilan menurut UU tersebut: 1. Asas keadilan menurut UU Pemda 2014 adalah bahwa setiap tindakan dalam penyelenggaraan negara harus mencerminkan keadilan secara proporsional bagi setiap warga negara. 2. Asas keadilan dan kesetaraan menurut UU ASN 2014 adalah bahwa pengaturan penyelenggaraan ASN harus mencerminkan rasa keadilan dan kesamaan untuk memperoleh kesempatan akan fungsi dan peran sebagai Pegawai ASN. 3. Asas keadilan menurut UU Ombudsman adalah 'cukup jelas'. Berdasarkan penjelasan tersebut, unsur-unsur yang terdapat dalam asas keadilan menurut UU Pemda 2014 adalah: 1. Setiap tindakan dalam penyelenggaraan negara; 2. Mencerminkan keadilan secara proporsional; 3. Bagi setiap warga negara.Sedangkan unsurunsur asas keadilan menurut UU ASN 2014 adalah: 1. Penyelenggaraan ASN; 2. 
Mencerminkan rasa keadilan dan kesamaan; 3. Untuk memperoleh kesempatan akan fungsi dan peran sebagai Pegawai ASN. Dari uraian tersebut, dapat dibedakan bahwa asas keadilan menurut UU Pemda 2014 memiliki ruang lingkup dan obyek pengaturan yang berbeda dengan UU ASN 2014. UU Pemda 2014 menekankan kepada setiap tindakan penyelenggara negara harus mencerminkan keadilan secara proporsional bagi setiap warga negara. Sedangkan UU ASN 2014, lebih mengatur bagaimana Penyelenggaraan ASN harus mencerminkan rasa keadilan dan kesamaan untuk memperoleh kesempatan akan fungsi dan peran sebagai Pegawai ASN. Jadi, ruang lingkup dan obyek UU ASN adalah Pegawai ASN yang berbeda dengan obyek UU Pemda 2014. Walaupun terdapat perbedaan, namun esensi asas keadilan yang dianut kedua undang-undang tersebut memiliki tujuan dan semangat yang sama. indikator yang termuat di dalam asas keadilan adalah sesuai dengan hukum dan sesuai dengan porsinya. Ada 10 (sepuluh) prinsip keadilan, yaitu, tanggung jawab, adaptif terhadap pendapat para ahli, berlaku baik kepada bawahan, rendah hati dan penyantun, tidak mementingkan diri sendiri, loyalitas tinggi, hidup sederhana, arif, cinta rakyat, tulus dan ikhlas. Nilai keadilan merupakan pertimbangan yang nilainya bersifat subyektif.

Adapun Asas-asas umum peradilan menurut UU dan Doktrin, sbb : 1. Asas Kepastian, 2.Asas Kepentingan, 3.Asas keterbukaan, 4. Asas Kemanfaatan, 5. Asas Ketidak berpihakan/ Tidak Diskriminatif .6 Asas Kecermatan, 7.Asas Tidak Menyalahgunakan Wewenang, 8 Asas Pelayanan Yang Baik, 9. Asas Tertib Penyelenggaraan Negara, 10. Asas Proporsionalitas, 11. Asas Profesionalitas.

\section{PENUTUP}

Mahkamah agung adalah lembaga tertinggi dalam system ketatanegaraan Indonesia yang merupakan pemegang kekuasaan kehakiman bersama-sama dengan Mahkamah Konstitusi. Mahkamah agung membawahi badan peradilan dalam lingkungan peradilan 
umum, lingkungan peradilan agama, lingkungan peradilan militer, lingkungan peradilan tata usaha Negara.

Istilah 'asas' dalam Asas Umum Peradilan yang Baik, atau sebagai 'asas hukum', yaitu suatu asas yang menjadi dasar suatu kaidah hukum. Asas hukum adalah asas yang menjadi dasar pembentukan kaidah-kaidah hukum, termasuk juga kaidah hukum tata pemerintahan. Kaidah atau norma adalah ketentuan-ketentuan tentang bagaimana seharusnya manusia bertingkah laku dalam pergaulan hidupnya dengan manusia lainnya.

Peradilan adalah pelaksanaan hukum dalam hal ada tuntutan hak yang konkret, fungsi mana dijalankan oleh suatu badan yang berdiri sendiri dan diadakan oleh negara serta bebas dari pengaruh apa atau siapapun dengan cara memberikan putusan yang bersifat mengikat dan bertujuan mencegah eigenrichting.

Ada Beberapa Asas-asas peradilan yang baik adalah,sbb :1.Penerapan Asas retroaktif, 2. Asas Persamaan di Mata Hukum, 3.Asas Persidangan yang terbuka untuk umum 4. Asas Perlindungan korban dan saksi

\section{DAFTAR PUSTAKA}

Darmini Roza dan Laurensius Arliman S Peran Pemerintah Daerah Di Dalam Melindungi Hak Anak Di Indonesia, Masalah-Masalah Hukum, Volume 47, Nomor 1, 2018.

Laurensius Arliman S, Komnas HAM dan Perlindungan Anak Pelaku Tindak Pidana, Deepublish, Yogyakarta, 2015.

Laurensius Arliman S, Penguatan Perlindungan Anak Dari Tindakan Human Trafficking Di Daerah Perbatasan Indonesia, Jurnal Selat, Volume 4, Nomor 1, 2016. 
Laurensius Arliman S, Problematika Dan Solusi Pemenuhan Perlindungan Hak Anak Sebagai Tersangka Tindak Pidana Di Satlantas Polresta Pariaman, Justicia Islamica, Volume 13, Nomor 2, 2016.

Laurensius Arliman S, Pelaksanaan Perlindungan Anak Yang Tereksploitasi Secara Ekonomi Oleh Pemerintah Kota Padang, Veritas et Justitia, Volume 2, Nomor 1, 2016.

Laurensius Arliman S, Kedudukan Ketetapan MPR Dalam Hierarki Peraturan PerundangUndangan Di Indonesia, Lex Jurnalica, Volume 13, Nomor 3, 2016.

Laurensius Arliman S, Komnas Perempuan Sebagai State Auxialiary Bodies Dalam Penegakan Ham Perempuan Indonesia, Justicia Islamica, Volume 14, Nomor 2, 2017.

Laurensius Arliman S, Peranan Pers Untuk Mewujudkan Perlindungan Anak Berkelanjutan Di Indonesia, Jurnal Ilmu Hukum Tambun Bungai, Volume 2, Nomor 2, 2017.

Laurensius Arliman S, Mewujudkan Penegakan Hukum Yang Baik Untuk Mewujudkan Indonesia Sebagai Negara Hukum, Jurnal Hukum Doctrinal, Volume 2, Nomor 2, 2017.

Laurensius Arliman S, Participation Non-Governmental Organization In Protecting Child Rights In The Area Of Social Conflict, The 1st Ushuluddin and Islamic Thought International Conference (Usicon), Volume 1, 2017.

Laurensius Arliman S, Partisipasi Masyarakat Dalam Pembentukan Perundang-Undangan Untuk Mewujudkan Negara Kesejahteraan Indonesia, Jurnal Politik Pemerintahan Dharma Praja, Volume 10, Nomor 1, 2017, https://doi.org/10.33701/jppdp.v10i1.379. 
Laurensius Arliman S, Peran Komisi Perlindungan Anak Indonesia Untuk Mewujudkan Perlindungan Anak, Jurnal Respublica Volume 17, Nomor 2, 2018.

Laurensius Arliman S, Menjerat Pelaku Penyuruh Pengrusakan Barang Milik Orang Lain Dengan Mempertimbangkan Asas Fungsi Sosial, Jurnal Gagasan Hukum, Volume 1, Nomor 1, 2019.

Laurensius Arliman S, Ilmu Perundang-Undangan Yang Baik Untuk Negara Indonesia, Deepublish, Yogyakarta, 2019.

Laurensius Arliman S, Isdal Veri, Gustiwarni, Elfitrayenti, Ade Sakurawati, Yasri, Pengaruh Karakteristik Individu, Perlindungan Hak Perempuan Terhadap Kualitas Pelayanan Komnas Perempuan Dengan Kompetensi Sumber Daya Manusia Sebagai Variabel Mediasi, Jurnal Menara Ekonomi: Penelitian dan Kajian Ilmiah Bidang Ekonomi, Volume 6, Nomor 2, 2020.

Laurensius Arliman S, Pendidikan Kewarganegaraan, Deepublish, Yogyakarta, 2020.

Laurensius Arliman S, Makna Keuangan Negara Dalam Pasal Pasal 23 E Undang-Undang Dasar 1945, Jurnal Lex Librum, Volume 6, Nomor 2 Juni 2020, http://dx.doi.org/10.46839/1ljih.v6i2.151.

Laurensius Arliman S, Kedudukan Lembaga Negara Independen Di Indonesia Untuk Mencapai Tujuan Negara Hukum, Kertha Semaya Journal Ilmu Hukum, Volume 8, Nomor 7, 2020.

Laurensius Arliman S, Pelaksanaan Assesment Oleh Polres Kepulauan Mentawai Sebagai Bentuk Pelaksanaan Rehabilitasi Bagi Pecandu Dan Korban Penyalahgunaan Narkotika, Jurnal Muhakkamah, Volume 5, Nomor 1, 2020. 
Laurensius Arliman S, Aswandi Aswandi, Firgi Nurdiansyah, Laxmy Defilah, Nova Sari Yudistia, Ni Putu Eka, Viona Putri, Zakia Zakia, Ernita Arief, Prinsip, Mekanisme Dan Bentuk Pelayanan Informasi Kepada Publik Oleh Direktorat Jenderal Pajak, Volume 17, No Nomor, 2020.

Larensius Arliman S, Koordinasi PT. Pegadaian (Persero) Dengan Direktorat Reserse Narkoba Polda Sumbar Dalam Penimbangan Barang Bukti Penyalahgunaan Narkotika, UIR Law Review, Volume 4, Nomor 2, 2020, https://doi.org/10.25299/uirlrev.2020.vol4(1).3779.

Laurensius Arliman S, Tantangan Pendidikan Kewarganegaraan Pada Revolusi 4.0, Ensiklopedia Sosial Review, Volume 2, Nomor 3, 2020.

Muhammad Afif dan Laurensius Arliman S, Protection Of Children's Rights Of The Islamic And Constitutional Law Perspective Of The Republic Of Indonesia, Proceeding: Internasional Conference On Humanity, Law And Sharia (Ichlash), Volume 1, Nomor $2,2020$.

Otong Rosadi danLaurensius Arliman S, Urgensi Pengaturan Badan Pembinaan Idelogi Pancasila Berdasarkan Undang-Undang Sebagai State Auxiliary Bodies yang Merawat Pancasila dalam Perspektif Hak Asasi Manusia, Prosiding Konferensi Nasional Hak Asasi Manusia, Kebudayaan dan Tujuan Pembangunan Berkelanjutan Indonesia pada Masa Pandemi Covid-19: Tantangan untuk Keilmuan Hukum dan Sosial Volume 1, Universitas Pancasila, Jakarta, 2020. 